\title{
Influence of recycled aggregates on properties of self-consolidating concretes
}

\author{
Lilia Señas $^{\mathrm{a}}$, Carla Priano ${ }^{\mathrm{a}, *}$, Silvina Marfil ${ }^{\mathrm{b}}$ \\ ${ }^{a}$ Department of Engineering, Universidad Nacional del Sur, Av. Alem 1253, (8000) Bahía Blanca, Argentina \\ ${ }^{\mathrm{b}}$ Department of Geology, Universidad Nacional del Sur, CIC Province of Buenos Aires - INGEOSUR, Bahía Blanca, Argentina
}

\section{H I G H L I G H T S}

- It is feasible to incorporate crushed concrete powder in order to achieve maximum use of the recycled concrete.

- The influence of admixtures must be studied not only in fresh mixtures but also in hardened concrete.

- Petrographic studies revealed that the incorporation of crushed concrete powder makes the mortar matrix denser.

\section{A R T I C L E I N F O}

\section{Article history:}

Received 4 September 2015

Received in revised form 1 March 2016

Accepted 17 March 2016

\section{Keywords:}

Self-consolidating concrete (SCC)

Recycled aggregates

Admixtures

\begin{abstract}
A B S T R A C T
Recycled aggregates are made from crushed waste concretes and can be used as a replacement of natural aggregates in concrete production. Despite having lower density and higher absorption than natural aggregates, they can be used to manufacture conventional concretes with good performance if they are added in the proper amounts. To make self-consolidating concretes, the same aggregates used to manufacture conventional concretes can be used, but in order to increase segregation resistance and keep mix cohesion, a large amount of fine aggregates and a suitable admixture are required. The main goal of this work is to study the influence of recycled aggregates on self-consolidating concrete. Concretes were mixed with $50 \%$ of the coarse aggregate replaced by recycled aggregates (Patagonia gravel) and with $20 \%$ of the fine aggregate (natural sand) replaced by crushed concrete powders. Fresh concrete properties were tested, and physical and mechanical properties were determined in the hardened state. The petrographic composition of the concrete was examined to assess the interfacial transition zone and the contribution of the powders to the mortar microtexture. The results vary depending on the type of admixture and aggregate. However, it is shown that the inclusion of these crushed aggregates to make good selfconsolidating concrete is feasible.
\end{abstract}

(C) 2016 Elsevier Ltd. All rights reserved.

\section{Introduction}

Self-consolidating concrete (SCC) is a special concrete that flows under its own weight, taking the formwork shape and filling all the empty spaces. The same aggregates are used to make SCC and conventional concretes (CC). However, the fine particles and type of admixture govern self-compactness properties in SCC fresh mixtures. To increase segregation resistance and keep cohesion, a large amount of fine aggregates is required in order to generate a higher water demand in the concrete due to the increase in the aggregate specific surface. In SCC, this effect is compensated for by using the latest generation of water-reducing admixtures.

\footnotetext{
* Corresponding author.

E-mail addresses: cpriano@uns.edu.ar (C. Priano), smarfil@uns.edu.ar (S. Marfil).
}

Recycled aggregates are obtained by crushing waste concrete and then, the coarse fraction of crushed aggregates can be used to replace natural coarse aggregates in the concrete production process. The advantages and disadvantages of using recycled aggregates have been extensively studied [1-3]. It was demonstrated that the mechanical behavior does not change significantly in concretes with a 75\% replacement of their natural aggregates by recycled ones [4]. In spite of presenting lower density and higher absorption than natural aggregates, it is feasible to make concretes with good performance by mixing the proper amount of each concrete component [5]. The use of recycled aggregates has a significant environmental impact since fewer natural resources are exploited and construction industry wastes may be used.

In the crushing process, there is a remaining fine fraction that can be incorporated during the concrete elaboration to replace part of the natural fine aggregates [6]. Several authors have stated that 
up to a $30 \%$ replacement does not substantially modify the mechanical properties or the durability of concrete $[7,8]$. This can be attributed to a lower effective water/cement ratio of the recycled concrete compared to the conventional one and to the angular shape and rough surface texture of the recycled aggregate particles forming a better paste-aggregate interfacial transition zone than in the natural aggregate [8]. One of the most significant differences between CC and concrete made with recycled aggregates is the presence of two different types of interfaces: one transition zone between the old mortar and the natural aggregate and the other between the new mortar and the natural aggregate. The failure mechanism of concretes containing recycled aggregates under mechanical loads depends on the quality of the two interface zones, the new and the old one [9].

Mineral additives such as calcareous filler, fly ash or granulated blast furnace slags modify the interfacial transition zone structure and/or reduce its thickness. The analysis of SEM images of SCC microstructure revealed that the calcareous filler decreases the interfacial transition zone porosity, enhances the adherence between the aggregate and the matrix, and reduces internal bleeding [10]. Even the use of treated sediments incorporated in SCC as a replacement of limestone filler and aggregates results in a dense solid matrix and a homogeneous material. The fine particles enhance the hydration process and the nucleation of hydrated products [11].

In Europe, India and other parts of the world filler materials such as fly ash and silica fume are available at little or no cost. However, in the regions where these materials are not available, the cost of SCC increases, thus making it uneconomical. Therefore, all attempts to develop SCC with alternative locally available materials will always be welcome in order to make SCC more economical [12].

In this work, the possibility of incorporating the remaining fine fraction from the crushing process to complete the SCC fine content required was examined. The utilization of all the fractions of recycled concrete allows the maximum use of crushed concrete, i.e., the coarse and fine fractions, and the crushed concrete powder.

Therefore, self-consolidating concretes were mixed with $50 \%$ of the coarse aggregate replaced by recycled aggregates (Patagonia gravel) and with $20 \%$ of the fine aggregate (natural sand) replaced by crushed concrete powders. Two experimental high-range water-reducing admixtures were used; they are both compatible with the cement used and allow making concretes denominated as "self-consolidating." The self-compactability of fresh concrete was evaluated, and the physical and mechanical properties were studied in the hardened state to evaluate the influence of recycled aggregates on self-consolidating concrete. Also, the petrographic composition of the concrete was studied to assess the interfacial transition zone and the contribution of the powders to the mortar microtexture.

\section{Materials and methods}

\subsection{Materials and mixtures}

The following materials were used to make the different mixtures:

- Normal Portland cement (CPN 40) (Type I, ASTM Standards) supplied by a manufacturer located in Buenos Aires area (Argentina).

- Water taken from the local water supply network at Bahía Blanca city (province of Buenos Aires, Argentina).

- Two types of aggregates:

a) Natural: composed of sand with a fineness modulus of 2.42 and gravel with a maximum nominal size of $12.5 \mathrm{~mm}$. Both meet grading specifications set by local IRAM standard 1627 [13] and come from a quarry located in the south of the province of Buenos Aires.

b) Recycled: made from crushing concrete with gravel as coarse aggregate from construction works in the Bahía Blanca area. The material to recycle was ground using a jaw crusher. During the grinding process, $80 \%$ of the
Table 1

Size distribution of natural sand and recycled fine aggregate.

\begin{tabular}{lll}
\hline \multirow{2}{*}{ Sieve } & \multicolumn{2}{l}{ Cumulative retained (\%) } \\
\cline { 2 - 3 } & Natural sand (NS) & Recycled fine aggregate \\
\hline $\mathrm{N}^{\circ} 4(4.75 \mathrm{~mm})$ & - & - \\
$\mathrm{N}^{\circ} 8(2.36 \mathrm{~mm})$ & 20 & 45 \\
$\mathrm{~N}^{\circ} 16(1.18 \mathrm{~mm})$ & 32 & 69 \\
$\mathrm{~N}^{\circ} 30(600 \mu \mathrm{m})$ & 41 & 80 \\
$\mathrm{~N}^{\circ} 50(300 \mu \mathrm{m})$ & 55 & 88 \\
$\mathrm{~N}^{\circ} 100(150 \mu \mathrm{m})$ & 94 & 95 \\
\hline
\end{tabular}

Table 2

Size distribution of gravel and recycled coarse aggregate.

\begin{tabular}{lcc}
\hline \multirow{2}{*}{ Sieve } & \multicolumn{2}{c}{ Cumulative retained $(\%)$} \\
\cline { 2 - 3 } & Gravel $(\mathrm{G})$ & Recycled coarse aggregate \\
\hline $1^{\prime \prime}(25 \mathrm{~mm})$ & - & - \\
$3 / 4^{\prime \prime}(19 \mathrm{~mm})$ & 2 & 4 \\
$1 / 2^{\prime \prime}(12.5 \mathrm{~mm})$ & 28 & 38 \\
$3 / 8^{\prime \prime}(9.5 \mathrm{~mm})$ & 66 & 74 \\
$\mathrm{~N}^{\circ} 4(4.75 \mathrm{~mm})$ & 100 & 100 \\
\hline
\end{tabular}

coarse fraction was obtained. The remaining $20 \%$ of the fine fraction has $5 \%$ of crushed concrete powder passing through sieve No. 100 . The coarse fraction was separated from the fine one in order to obtain a recycled coarse aggregate of maximum nominal size similar to that of the boulder $(12.5 \mathrm{~mm})$ and a recycled fine aggregate with a fineness modulus of 3.77. Both fractions were sprinkled with water before adding to concrete.

To complete the SCC fine content required, calcareous filler and crushed concrete powder, passing through a $149 \mu \mathrm{m}$ mesh size (sieve No. 100 - ASTM Standards), obtained as remaining fraction during the concrete crushing process, were used.

The size distributions of natural and recycled aggregates are shown in Tables 1 and 2.

These materials were used to make six different concretes with a water/cement ratio of 0.50 (water/cementitious materials ratio of 0.40 ). Two "experimental" highrange water-reducing admixtures (water-based modified polycarboxylate) called "S" and " $\mathrm{H}$ ", were used to make two different groups of 3 samples each. In both groups, a reference concrete made with rounded gravel and natural sand (SP and HP) was used. Then, a concrete with a replacement of $50 \%$ by volume of the natural coarse aggregate by a recycled one (SRG and HRG) was prepared. Finally, 20\% of the natural fine aggregate was replaced by recycled fine aggregate (SRGF and HRGF). The designations and characteristics of each sample are shown in Table 3 and the mixture proportions in Table 4.

From Table 3, it can be noticed that to achieve the same consistency, it was necessary to increase the amount of both admixtures (\% by cement weight) for the samples that contained recycled coarse aggregate and crushed sand.

Due to the amount and types of fine aggregates and admixtures, SCC always required a greater kneading time than $\mathrm{CC}$ to be able to achieve proper mixture homogeneity.

\subsection{Experimental}

\subsubsection{Admixture/cement compatibility}

To optimize the admixture amount to be used in pastes, the saturation dosage for the water/cement/admixture system was determined by the Marsh cone test. The use of an admixture amount beyond the saturation point does not modify paste fluidity and could have negative effects (delaying setting times, segregation) besides increasing concrete costs [14]. This test also allows evaluating other effects of the superplasticizers such as the loss of fluidity in cement pastes with time.

In the present study, a Marsh cone with a nozzle of $8 \mathrm{~mm}$ diameter was used; $800 \mathrm{ml}$ of paste was poured into the cone and the time taken by $200 \mathrm{ml}$ to flow was determined. The flow time was measured at 5 and $60 \mathrm{~min}$ after the pastes were prepared. The longer the flow time is, the lower the fluidity results. The saturation point can be determined applying this procedure with different amounts of admixtures. This point indicates the optimum admixture dosage beyond which the flow time does not decrease appreciably [15]. A water/cement ratio of 0.45 was used, and the superplasticizer dosage varied from $0.1 \%$ to $2 \%$ by cement weight.

To establish the water content contributed by admixtures, in order to deduct it from the mixing water amount, the solid content [16] of each of them was determined. For admixture " $H$ " it was $49 \%$ and for admixture " $\mathrm{S}$ ", $41 \%$. These values were taken into account when mixing the pastes for the Marsh cone test. 
Table 3

Sample characteristics. G: rounded gravel; NS: natural sand; Rec: recycled.

\begin{tabular}{|c|c|c|c|c|}
\hline Mixtures & Admixture & Dosage (\%) & Coarse aggregate & Fine aggregate \\
\hline SP & $\mathbf{S}$ & 1.00 & G & NS \\
\hline SRG & Honey colored liquid, lightly opaque. Density at $20^{\circ} \mathrm{C}: 1.12 \mathrm{~kg} / \mathrm{l} \mathrm{PH}: 5 \pm 1$ & 1.20 & $50 \%$ G $+50 \%$ Rec. & NS \\
\hline SRGF & & 1.40 & $50 \%$ G + 50\% Rec. & $80 \%$ NS + 20\% Rec. \\
\hline HP & $\mathbf{H}$ & 0.70 & G & NS \\
\hline HRG & Translucent liquid. Density at $20^{\circ} \mathrm{C}: 1.09 \mathrm{~kg} / \mathrm{l} \mathrm{PH}: 4 \pm 1$ & 1.30 & $50 \%$ G $+50 \%$ Rec. & NS \\
\hline HRGF & & 1.50 & $50 \%$ G + 50\% Rec. & $80 \%$ NS + 20\% Rec. \\
\hline
\end{tabular}

Table 4

Mixture proportions for $1 \mathrm{~m}^{3}$ of SCC.

\begin{tabular}{|c|c|c|c|c|c|c|c|}
\hline Mixtures & $\begin{array}{l}\text { Cement + Filler } \\
(\mathrm{kg})\end{array}$ & Water (l) & Natural sand (kg) & Gravel (kg) & Recycled fine aggregate $(\mathrm{kg})$ & Recycled coarse aggregate (kg) & Admixture dosage ( $\mathrm{kg}$ ) \\
\hline SP & 415 & 166 & 1065 & 750 & - & - & 4.15 \\
\hline SRG & 415 & 166 & 1065 & 375 & - & 333 & 4.98 \\
\hline SRGF & 415 & 166 & 852 & 375 & 195 & 333 & 5.81 \\
\hline HP & 415 & 166 & 1065 & 750 & - & - & 2.91 \\
\hline HRG & 415 & 166 & 1065 & 375 & - & 333 & 5.40 \\
\hline HRGF & 415 & 166 & 852 & 375 & 195 & 333 & 6.23 \\
\hline
\end{tabular}

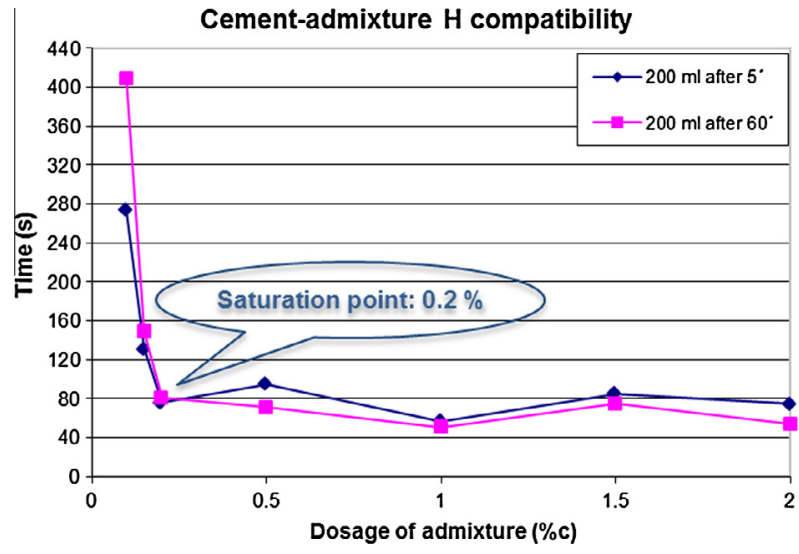

Fig. 1. Flow time in pastes for different amounts of $\mathrm{H}$ admixture.

Figs. 1 and 2 display the results of the Marsh cone test for samples with $\mathrm{H}$ and $\mathrm{S}$ admixture, respectively. Both graphs show that complete compatibility exists between the admixtures and the cement used, since the superplasticizer dosage at the saturation point and 5 and 60 min curves are really close. Therefore, it can be guaranteed that fluidity is kept constant for at least $1 \mathrm{~h}$. On the other hand, the cement-admixture combinations that do not exhibit a well-defined saturation point and the 60 min curve is shifted upwards and on the right of the 5 min curve may indicate incompatibility.

With the Marsh cone test the optimum dosages (saturation point for cement pastes) for both superplasticizers were: for $\mathrm{H}$ admixture $0.2 \%$ and for $\mathrm{S}$ admixture $0.3 \%$ by cement weight.

\subsubsection{Tests on SCC in fresh state}

The basic SCC properties (fluidity, segregation resistance, deformability and viscosity of fresh concrete) were evaluated and quantified by standardized tests that take into account SCC ability to fill empty spaces, such as passing through obstacles without losing its homogeneity or creating obstructions. The following tests were conducted:

- Slump-flow test [17]: $\mathrm{T}_{50}$ (time taken by the concrete to reach the $50 \mathrm{~cm}$ diameter mark) and $\mathrm{d}_{\max }$ (final diameter reached by the mixture).

- J-ring test [18]: $\mathrm{h}_{1}-\mathrm{h}_{2}$ (concrete heights in the interior and exterior ring edges),

$\mathrm{T}_{50}$ (time taken by the concrete to reach the $50 \mathrm{~cm}$ diameter mark) and $\mathrm{d}_{\max }$

(final diameter of the mixture).

- V-funnel test (V-funnel): $\mathrm{T}_{\mathrm{v}}$ (time taken to drain the complete concrete volume).

As in several cases high-range water-reducing admixtures may incorporate air in the fresh concrete mass, their content was determined by the pressure method [19].

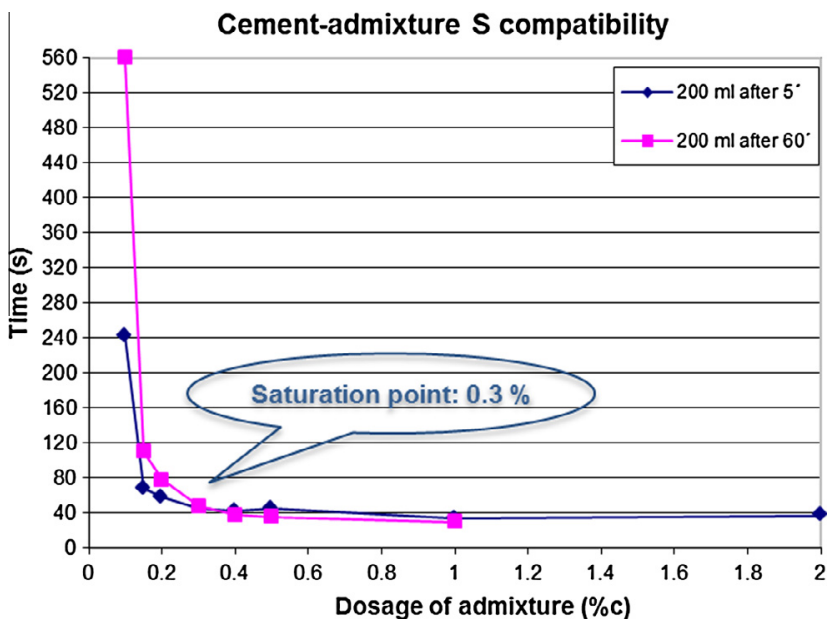

Fig. 2. Flow time in pastes for different amounts of $\mathrm{S}$ admixture.

\subsubsection{Tests on SCC in hardened state}

Cylindrical samples of a $15 \mathrm{~cm}$ diameter and a height of $30 \mathrm{~cm}$ were molded and cured, following Argentina's current regulation [20] to perform the compressive strength test [21] and splitting tensile strength test [22] at 28 days. After casting, all specimens were kept in the laboratory for $24 \mathrm{~h}$ until they had developed enough strength to be demolded and then, they were placed in a wet chamber with a relative humidity of $100 \%$ and a constant temperature of $20^{\circ} \mathrm{C}$, until the curing period was complete.

To perform a capillary suction test, cylindrical samples of $10 \times 20 \mathrm{~cm}$ were molded [23], and the capillary suction capacity (C) and sorptivity (S) were determined. The former represents the water amount by unit area that the tested sample is able to absorb until reaching a constant mass, and the latter measures the velocity at which water penetrates the concrete pore structure.

\subsubsection{Petrographic studies}

A petrographic study was performed on all samples to evaluate the interfacial transition zone and the contribution of crushed concrete powders to the mortar microtexture. An Olympus B2-UMA trinocular petrographic microscope was used.

\section{Results and discussion}

In all samples, fluidity was significantly modified when the admixture was mixed. To replace the natural aggregate by the recycled one, the amount of admixture proposed by the manufacturer has to be increased in order to reach a similar consistency to 


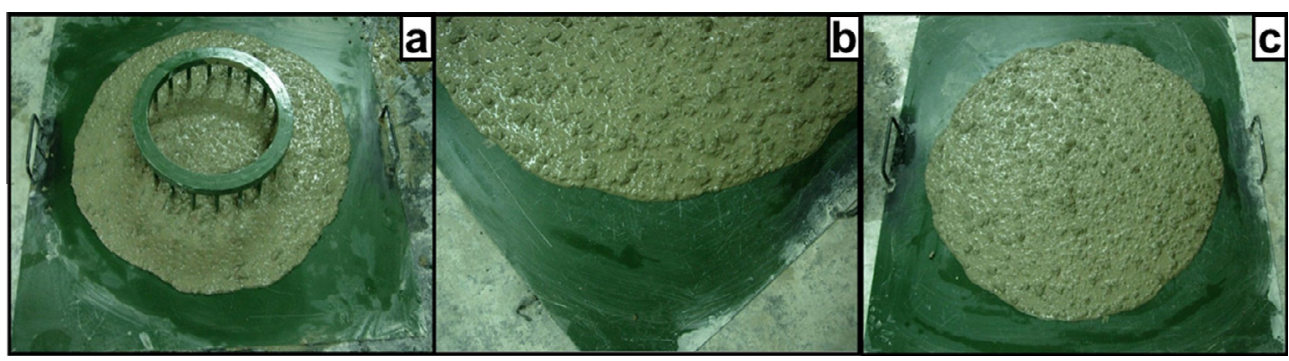

Fig. 3. Tests in the fresh state. a. Sample SRG after the J-ring test, b. Edge of sample HRGF after the extended test, c. Extended test of sample HRGF.

Table 5

Fresh state results.

\begin{tabular}{|c|c|c|c|c|c|c|c|}
\hline \multirow[t]{2}{*}{ Mixtures } & \multirow{2}{*}{$\begin{array}{l}\text { Air content } \\
(\%)\end{array}$} & \multicolumn{2}{|c|}{ Slump-flow } & \multicolumn{3}{|l|}{ J-ring } & \multirow{2}{*}{$\begin{array}{l}\text { V-funnel } \\
T_{v}(s)\end{array}$} \\
\hline & & $\mathrm{T}_{50}(\mathrm{~s})$ & $\mathrm{d}_{\max }(\mathrm{cm})$ & $\mathrm{h}_{1}-\mathrm{h}_{2}(\mathrm{~mm})$ & $\mathrm{T}_{50}(\mathrm{~s})$ & $\mathrm{d}_{\max }(\mathrm{cm})$ & \\
\hline SP & 2.5 & 4.3 & 71 & 10 & 7.5 & 66 & 8.5 \\
\hline SRG & 2.5 & 3.9 & 68 & 10 & 6.1 & 67 & 9.6 \\
\hline SRGF & 2.0 & 3.9 & 70 & 15 & 7.8 & 66 & 12.6 \\
\hline $\mathrm{HP}$ & 1.5 & 2.7 & 62 & 20 & 10.8 & 57 & 7.5 \\
\hline HRG & 1.5 & 5.9 & 64 & 15 & 12.3 & 59 & 9.9 \\
\hline HRGF & 1.0 & 10.5 & 61 & 20 & 13.8 & 60 & 14.0 \\
\hline
\end{tabular}

Table 6

Tests results in hardened state (measured at 28 days).

\begin{tabular}{|c|c|c|c|c|c|c|c|c|c|}
\hline \multirow[t]{2}{*}{ Sample } & \multicolumn{2}{|c|}{$\begin{array}{l}\text { Compressive strength } \\
\text { (MPa) }\end{array}$} & \multicolumn{2}{|c|}{ Tensile strength (MPa) } & \multicolumn{2}{|l|}{$\mathrm{C}$} & \multicolumn{2}{|l|}{$\mathrm{S}$} & \multirow[t]{2}{*}{$\mathrm{R}^{2}$} \\
\hline & Mean & St. dev. & Mean & St. dev. & $\left(\mathrm{g} / \mathrm{m}^{2}\right)$ & $(\%)$ & $\left(\mathrm{g} / \mathrm{m}^{2} \mathrm{~s}^{0,5}\right)$ & $(\%)$ & \\
\hline SP & 51.2 & 2.6 & 4.6 & 0.3 & 2615 & 100 & 3.9 & 100 & 0.993 \\
\hline SRG & 48.1 & 2.1 & 4.1 & 0.3 & 2949 & 113 & 4.8 & 123 & 0.988 \\
\hline SRGF & 45.6 & 2.4 & 3.8 & 0.4 & 3462 & 132 & 6.1 & 156 & 0.991 \\
\hline HP & 47.6 & 2.4 & 4.4 & 0.4 & 3161 & 100 & 5.3 & 100 & 0.985 \\
\hline HRG & 46.6 & 2.1 & 4.3 & 0.5 & 3333 & 105 & 5.5 & 104 & 0.989 \\
\hline HRGF & 47.0 & 2.1 & 3.9 & 0.2 & 3526 & 112 & 6.2 & 117 & 0.996 \\
\hline
\end{tabular}

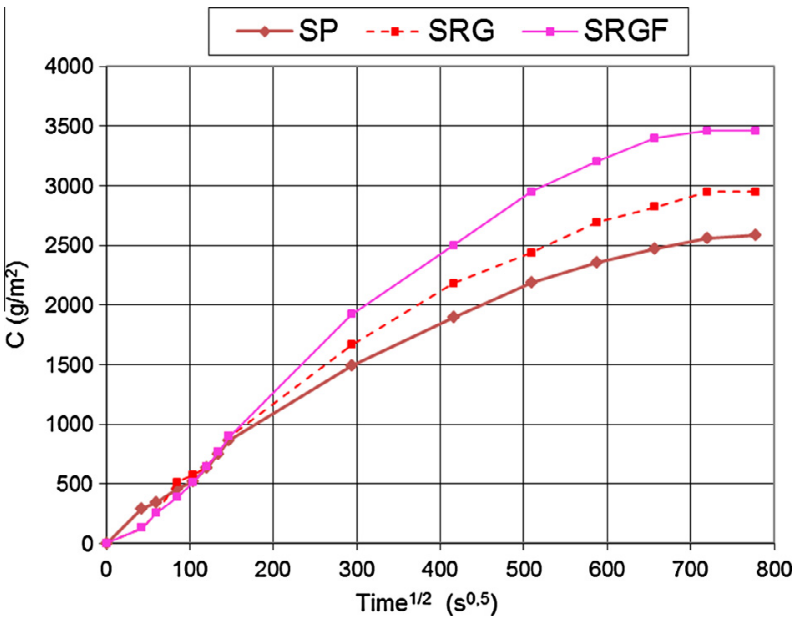

Fig. 4. Capillary suction test for samples made with S admixture.

that of the reference concretes. The recycled fine aggregate has a rough texture and greater water absorption than natural sand. Regarding $\mathrm{S}$ admixture, the required fluidity was met using a smaller amount than the maximum recommended by the manufacturer ( $2 \%$ by cement weight), while $\mathrm{H}$ admixture required the recommended maximum amount ( $1.5 \%$ by cement weight).

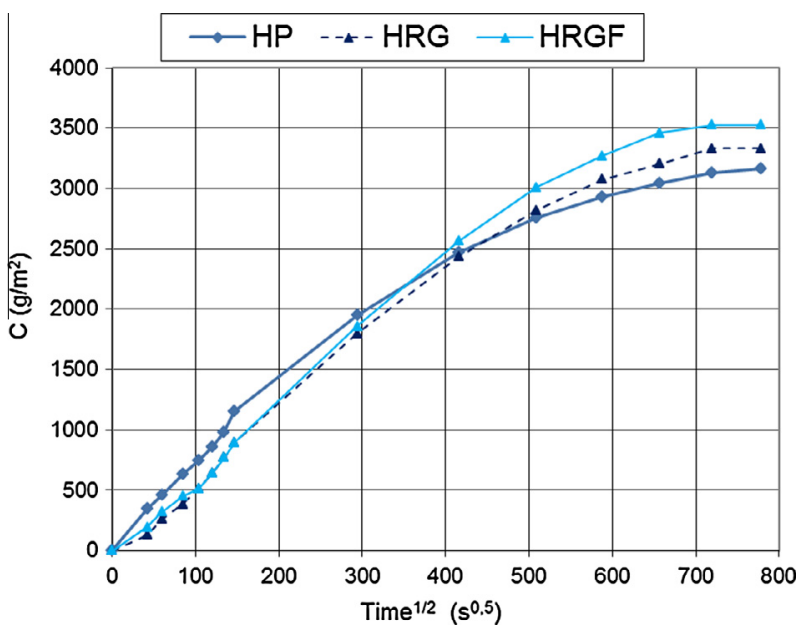

Fig. 5. Capillary suction test for samples made with $\mathrm{H}$ admixture.

In all cases, the samples had a good appearance; there were no signs of segregation or bleeding. Samples incorporating the fine recycled fraction presented a rougher appearance and some macro air bubbles. 

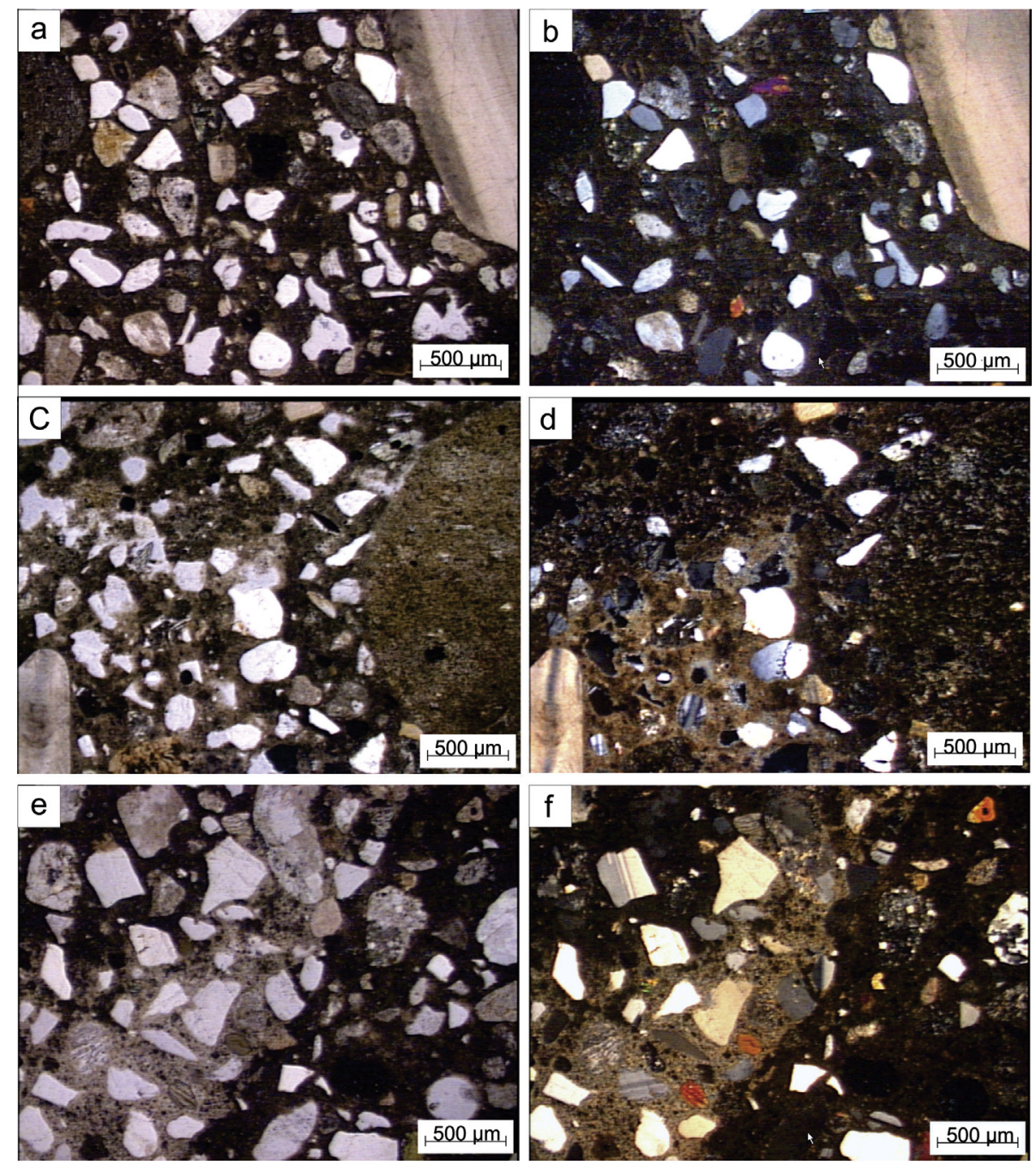

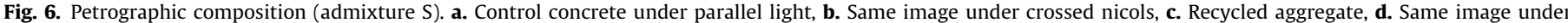
crossed nicols, e. Recycled aggregate with evidence of carbonation, f. Same image under crossed nicols.

\subsection{Results of tests on SCC in fresh state}

Fig. 3a shows the appearance of sample SRG after the J-ring test and Fig. 3b, the edge of sample HRGF after the extended test (Fig. 3c). Sample test results are summarized in Table 5.

Concretes made by using $\mathrm{S}$ admixture incorporated a greater air amount than those made with admixture $\mathrm{H}$. In both cases, mixtures containing crushed concrete powder had lower air content than the other two mixtures (reference mixture and 50\% recycled coarse aggregate).

In all studied cases, the results listed in Table 5 are within the recommended SCC limits according to the bibliography [24,25] and give a reference for the self-compactability conditions of the mixtures. The repeatability of the results was checked in all tests.

Taking into account the classification given by The European Guidelines for Self-compacting Concrete [2], SCC made with S admixture can be classified as SF2 class $\left(\mathrm{d}_{\max }=66-75 \mathrm{~cm}\right)$ and the ones made with admixture $H$ as class $S F 1\left(d_{\max }=55-65 \mathrm{~cm}\right)$, according to extended test results. For both admixtures studied, the flow class was not modified when the coarse and the fine natural aggregates were replaced by the recycled one.

Regarding the $\mathrm{T}_{50}$ value measured during the slump test, it was noticed that in mixtures containing admixture $\mathrm{H}$, the viscosity changed as the replacement of natural aggregate with recycled material increased. For samples made with admixture $S$, this parameter did not change. All mixtures can be classified as VS2 $\left(\mathrm{T}_{50}>2 \mathrm{~s}\right)$.

V-funnel test results classify SSC as VF2 $\left(T_{v}>8 \mathrm{~s}\right)$ except for the HP mixture that is VF1 $\left(T_{\mathrm{V}} \leqslant 8 \mathrm{~s}\right)$. The evaluated plastic viscosity using the $\mathrm{V}$-funnel method increased as the percentage of recycled aggregate replacing the natural one increased as well. This effect was more significant in mixtures containing $\mathrm{H}$ admixture.

The difference between the final diameter reached during the free extended test and the J-ring test is below or equal to $50 \mathrm{~mm}$, therefore the passing ability between reinforcements is considered acceptable for all samples.

\subsection{Results of tests on SCC in hardened state}

Hardened concrete tests results are summarized in Table 6 (mean value and standard deviation). Compressive strength values correspond to the average of five measurements and those for the splitting tensile test, to the average of three measurements Table 6 also lists values for: capacity (C), sorptivity (S) and the proper correlation coefficient of least squares adjustment $\left(R^{2}\right)$.

In mixtures made with $S$ admixture, compression and tensile strength values decrease as the replacement by recycled aggregate increases. Compression strength decreases by $6 \%$ when the recy- 

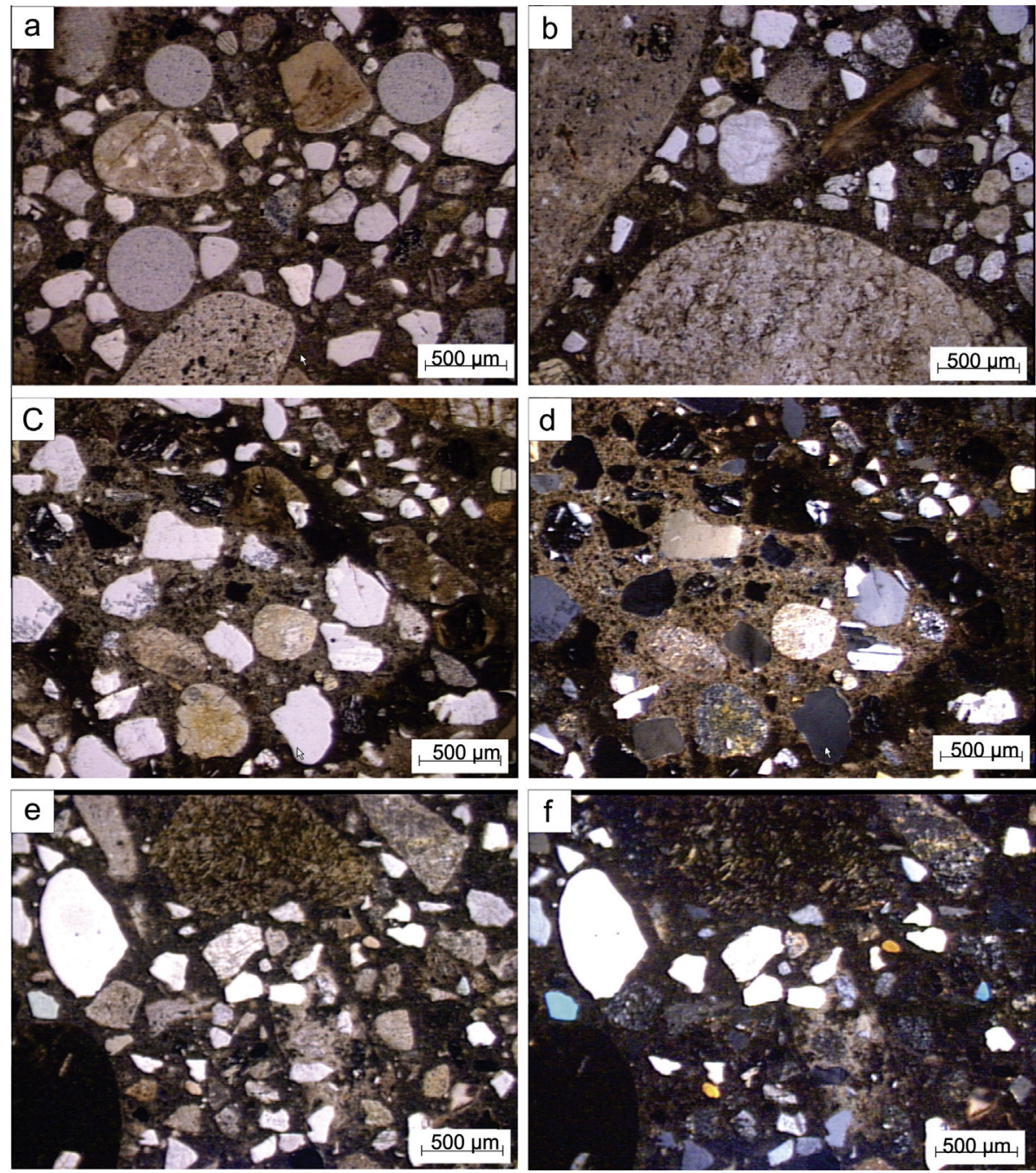

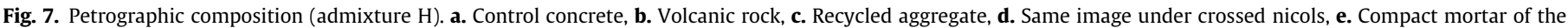
recycled concrete, f. Same image under crossed nicols.

cled coarse aggregate (SRG) is incorporated and 5\% more after the addition of the crushed fine aggregate (SRGF). Tensile strength decreased by about $11 \%$ and $17 \%$ compared to the reference concrete. These reductions are average values.

In the mixture containing $\mathrm{H}$ admixture, there were no significant differences in compressive strength values as the amount of recycled aggregate was increased. Tensile strength decreased by $2 \%$ and $11 \%$ compared to the reference concrete when the recycled coarse (HRG) and fine (HRGF) aggregates were added.

Concrete strength depends on the matrix, aggregate and interfacial transition zone. In this case, the recycled aggregate characteristics caused a decrease in strength with respect to the control concrete, which was not compensated by the presence of crushing concrete powders that made the mortar matrix denser (see 3.3 Petrographic studies).

Incorporating recycled aggregates to mixtures containing admixture $S$ caused a significant increase in capacity and capillary absorption speed values in comparison to the reference concrete (13-32\% and $23-56 \%$, respectively).

In contrast, mixtures containing admixture $\mathrm{H}$ showed a slight increase in capacity and sorptivity values $(5-12 \%$ and $4-17 \%$, respectively) as the natural aggregate was replaced by the recycled one. Despite the higher water absorption of the recycled aggregates than the natural ones, the behavior during the capillary suction absorption test was similar, the high-range water reducer being the only different component in samples from groups $\mathrm{S}$ and $\mathrm{H}$.

Figs. 4 and 5 show the curves of the mass per unit area increase vs. the square root of time, calculated during the capillary suction tests of each of the studied admixtures.

Figs. 4 and 5 show the mass gain as a function of time for the different samples. It is higher in the concrete containing recycled aggregate than in the control concrete. This increase in capillarity is due to the mortar present in the recycled aggregate. The different is more significant in the mixtures made with admixture $\mathrm{S}$.

\subsection{Petrographic studies}

The control concrete was made with polymictic gravel mainly composed of volcanic rocks, and natural sand composed of quartz, feldspar, carbonate valves, pyroxenes, chalcedony, and granitic and volcanic rocks.

Fig. 6a shows the composition of the fine aggregate of the control concrete (with the $S$ admixture) under parallel light and the mortar with no evidence of microcracking. Fig. $6 \mathrm{~b}$ is the same image but under crossed nicols. The recycled aggregate has a similar mineralogical and petrographic composition to that of the control concrete. Fig. $6 \mathrm{c}$ shows a sector with a particle of recycled 
aggregate (mainly composed of the original mortar) in net contact with the cementitious matrix. Observations under parallel light make the identification of the sector difficult. In Fig. $6 \mathrm{~d}$ the area can be differentiated due to higher birefringence caused by the carbonation process developed before its incorporation to the concrete.

Fig. 6e and f show the concrete with $50 \%$ of recycled coarse aggregate and $20 \%$ of crushed concrete powders (admixture S) observed under parallel light and crossed nicols, respectively. The paste is darker and more compact than the previous ones. The recycled aggregate-mortar contact is net, and no microcracking are observed. The recycled aggregate shows evidence of carbonation in the paste (higher birefringence).

The microtexture and composition of the control concrete made with admixture $\mathrm{H}$ are depicted in Fig. 7. Fig. 7a shows a concrete with no signs of microcracking and high porosity of the paste evidenced by an increase in the number of air voids. Fig. 7b shows another sector where it is possible to observe that in the composition of the coarse aggregate volcanic rocks prevail. No microcracking is observed.

Fig. 7c shows the concrete with admixture $\mathrm{H}$ and a $50 \%$ replacement of recycled coarse aggregate. The recycled aggregate-mortar interface is good. The original mortar that constitutes the recycled mortar shows carbonation, which provides higher birefringence to the paste when it is observed under crossed nicols (Fig. 7d). Porosity is lower than in the control concrete. Fig. 7e and f correspond to SCC with coarse aggregate and crushed concrete powders (admixture $\mathrm{H}$ ) viewed under parallel light and crossed nicols, respectively. A particle of recycled concrete is observed in net contact with a compact and mortar. Porosity is lower than that of the standard concrete.

Comparison of the results revealed that the air voids are empty, abundant and large, in some cases $>1 \mathrm{~mm}$ long. The SCC paste made with admixture $S$ shows higher birefringence (when viewed under crossed nicols) than the paste made with admixture $\mathrm{H}$, and under parallel light it is lighter. However, concrete pastes containing both admixtures and $20 \%$ of crushed concrete powders are similar, but they are darker and thicker than those without them. That is, their incorporation made the mortar matrix denser.

Among the different SCCs tested, no variations were observed in the recycled aggregate-mortar interfacial transition zone, which is net and often difficult to differentiate. The good adherence of the recycled aggregates to the natural aggregate was not modified by the incorporation of crushed concrete powders.

No differences in the microtextures were observed between the SCC mortars with $50 \%$ of recycled coarse aggregates and those containing $20 \%$ of crushed concrete powders. Particles of the recycled mortars generally show evidence of carbonation.

\section{Conclusions}

- Both studied admixtures turned out to be compatible with the cement used. The incorporation of recycled aggregates makes it necessary to use larger admixture amounts compared to reference mixtures to obtain the same consistency.

- The mixtures made with recycled aggregates showed a good appearance, without any signs of segregation or bleeding.

- The compressive and tensile strength of mixtures containing admixture $S$ decreased as the replacement of natural aggregate by a recycled one increased. The influence of the recycled coarse and fine aggregates was more significant in the splitting tensile test. Compressive strength values for mixtures with $\mathrm{H}$ admixture and recycled aggregate replacement were similar to that of the reference concrete, while tensile strength values decreased slightly.
- Mixtures containing S admixture and recycled coarse and fine aggregates showed an increase in absorption values compared to reference mixtures. Mixtures with admixture $\mathrm{H}$ showed a slight increase in capillary suction parameters as the natural aggregate was replaced by the recycled aggregate, despite the higher water absorption of the recycled aggregates than the natural ones.

- Results indicate that the proper selection of the admixture to be used to make SCC allows the replacement of $50 \%$ of the coarse aggregate and $20 \%$ of the natural fine aggregate, in order to obtain a good performance material to be used in resistant structures. The influence of admixtures must be studied not only in fresh mixtures but also in hardened concrete.

- The petrographic study performed revealed that the incorporation of crushed concrete powder makes the mortar matrix denser. Excellent adherence between the recycled aggregate and the mortar was observed in the interfacial transition zone.

- It is feasible to incorporate crushed concrete powder as recycled fine aggregate in order to achieve maximum use of the treated materials (coarse aggregate, sand and powders).

\section{Acknowledgements}

Authors are grateful to the Engineering and Geology Department of the Universidad Nacional del Sur and to the Comision de Investigaciones Científicas of the province of Buenos Aires for their support.

\section{References}

[1] T. Hansen, H. Narud, Strength of recycled concrete made from crushed concrete coarse aggregate, Concr. Int. 5 (1) (1983) 79-83.

[2] A. Padmini, K. Ramamurthy, M. Mathews, Influence of parent concrete on the properties of recycled aggregate concrete, Constr. Build. Mater. 23 (2) (2009) 829-836, http://dx.doi.org/10.1016/j.conbuildmat.2008.03.006.

[3] C. Zega, Y. Villagrán-Zaccardi, A. Di Maio, Effect of natural coarse aggregate type on the physical and mechanical properties of recycled coarse aggregates, Mater. Struct. 43 (1-2) (2010) 195-202, http://dx.doi.org/10.1617/s11527009-9480-4.

[4] L. Señas, C. Priano, J. Valea, G. Cabo, Reciclado de hormigón de canto rodado patagónico, Proceedings of the 16 ${ }^{\mathrm{a}}$ Reunión Técnica de la Asociación Argentina de Tecnología del Hormigón, 2006, pp. 15-22. Mendoza, Argentina.

[5] Y. Lin, Y. Tyan, T. Chang, C. Chang, An assessment of optimal mixture for concrete made with recycled concrete aggregates, Cem. Concr. Res. 34 (8) (2004) 1373-1380, http://dx.doi.org/10.1016/j.cemconres.2003.12.032.

[6] S. Kou, C. Poon, Properties of self-compacting concrete prepared with coarse and fine recycled concrete aggregates, Cement Concr. Compos. 31 (9) (2009) 622-627, http://dx.doi.org/10.1016/j.cemconcomp.2009.06.005.

[7] L. Evangelista, J. de Brito, Mechanical behaviour of concrete made with fine recycled concrete aggregates, Cement Concr. Compos. 29 (5) (2007) 397-401, http://dx.doi.org/10.1016/j.cemconcomp.2006.12.004.

[8] C. Zega, A. Di Maio, Use of recycled fine aggregate in concretes with durable requirements, Waste Manage. 31 (11) (2011) 2336-2340, http://dx.doi.org/ 10.1016/j.wasman.2011.06.011.

[9] J. Xiao, W. Li, Z. Sun, S. Shah, Crack propagation in recycled aggregate concrete under uniaxial compressive loading, ACI Mater. J. 109 (4) (2012) 451-461.

[10] M. Collepardi, A. Borsoi, S. Collepardi, R. Troli, Strength, shrinkage and creep of SCC and flowing concrete, in: S.P. Shah (Ed.), Proceedings of the Second North American Conference on the Design and Use of Self-Consolidation Concrete and Fourth International RILEM Symposium on Self-Compacting Concrete, Chicago, MI, USA, vol. 2, 2005, pp. 911-919.

[11] E. Rozière, M. Samara, A. Loukili, D. Damidot, Valorisation of sediments in selfconsolidating concrete: mix-design and microstructure, Constr. Build. Mater. 81 (2015) 1-10, http://dx.doi.org/10.1016/j.conbuildmat.2015.01.080.

[12] S. Ahmad, S. Adekunle, M. Maslehuddin, Azad.A. Kalam, Properties of selfconsolidating concrete made utilizing alternative mineral fillers, Constr. Build. Mater. 68 (2014) 268-276, http://dx.doi.org/10.1016/j.conbuildmat.2014. 06.096.

[13] IRAM 1627, Agregados. Granulometría de los agregados para hormigón, Instituto Argentino de Racionalización de Materiales, Buenos Aires, 1997. 23p.

[14] R. Gettu, J. Izquierdo, P. Gomes, A. Josa, Development of high-strength selfcompacting concrete with fly ash: a four-step experimental methodology, 27th Conference on Our world in concrete and structures. Singapore (2002) $217-224$. 
[15] P. Aïtcin, M. Baalbaki, Concrete admixtures - key components of modern concrete, in: A. Aguad, R. Gettu, S.P. Shah (Eds.), Concrete Technology: New Trends and Industrial Applications, E\&FN Spon, London, 1994, pp. 33-47.

[16] IRAM 1663, Hormigón de cemento. Aditivos químicos, Instituto Argentino de Racionalización de Materiales, Buenos Aires, 2002. 20p.

[17] ASTM Standard C1611-14, Standard Test Method for Slump Flow of SelfConsolidating Concrete, ASTM International, 2014, p. 6.

[18] ASTM C1621-09, Standard Test Method for Passing Ability of Self-Consolidating Concrete by J-Ring, ASTM International, 2009, p. 5.

[19] IRAM 1602, Hormigón De Cemento Pórtland. Método Por Presión Para La Determinación Del Contenido De Aire En Mezclas Frescas De Hormigones Y Morteros - Método A, Instituto Argentino de Racionalización de Materiales, Buenos Aires, 1988. 12.

[20] IRAM 1534, Hormigón. Preparación Y Curado De Probetas En Laboratorio Para Ensayos De Compresión Y Tracción Por Compresión Diametral, Instituto Argentino de Racionalización de Materiales, Buenos Aires, 2004. 15p.
[21] IRAM 1546, Hormigón De Cemento. Método De Ensayo De Compresión, Instituto Argentino de Racionalización de Materiales, Buenos Aires, 2013. 13p.

[22] IRAM 1658, Hormigón. Determinación De La Resistencia a La Tracción Simple Por Compresión Diametral, Instituto Argentino de Racionalización de Materiales, Buenos Aires, 1995. 9p.

[23] IRAM 1871, Método de ensayo para determinar la capacidad y la velocidad de succión capilar de agua del hormigón endurecido, Instituto Argentino de Racionalización de Materiales, Buenos Aires, 2004. 12p.

[24] M. Ouchi, M. Hibino, K. Ozawa, H. Okamura, A rational mix-design method for mortar in self-compacting concrete, Proceedings of the Sixth East Asia-Pacific Conference on Structural Engineering \& Construction, Taipei, ROC 2 (1998) 1307-1312.

[25] EPG: Self-Compacting Concrete European Project Group, The European Guidelines for Self- Compacting concrete: Specifications, Production and Use. 2005, 63p. 